\title{
Genetic instability of mouse embryonic germinative G1 cell line and disfunction of the mitotic checkpoint and p53
}

\author{
A. P. Iatsyshyna, S. M. Kvasha, O. V. Pidpala, T. P. Ruban, I. M. Vagina, L.L.Lukash
}

The Institute of Molecular Biology and Genetics

150 Zabolotny Str., Kyiv 03143, Ukraine

a.p.iatsyshyna@imbg.org.ua

\begin{abstract}
The ability of cells of mouse G1 cell line to survive after treatment with different concentrations of colchicine has been analysed. We have shown that G1 cells at $26^{\text {th }}$ and $114^{\text {th }}$ passages are less sensitive to the treatment with colchicine than BALB/c mouse embryonic fibroblasts. These results indicate attenuation of the mitotic checkpoint of $G 1$ cells. The expression of 53 has been detected at low levels in cells of G1 cell line and its sublines G1-OA and G1-T by Western blotting. It has been shown by immunoprecipitation that G1 cells contain wild type and mutant p53 that could lead to the disfunction of p53. Genetic instability of G1 cell line is possibly associated with the failure of the mitotic checkpoint and functional inactivation of 53.
\end{abstract}

Key words: mouse cell in vitro, mitotic checkpoint, chromosomal instability, p53

Introduction. Chromosomal instability i.e. loss or gain of chromosomes, also aneuploidy, is often observed in various human tumours and is considered to be one of the markers of solid tumours [1]. The changes in ploidy are more significant at the later stages of tumour development, and thus chromosomal instability correlates with acquisition of malignant phenotypes [2,3]. There is a concept that chromosomal instability is a mutator, increasing the number of mutations, which result in tumour formation [4]. The molecular bases of chromosomal instability have not been studied enough, however, recently much attention has been paid to the issue of genetic and epigenetic changes of the mitotic checkpoint (or the checkpoint of spindle assembly), which functions as the provider of equal distribution of chromosomes between two daughter cells [5-7]. As the majority of cells are incapable of terminating their division

(C) A. P. IATSYSHYNA, S. M. KVASHA, O. V. PIDPALA, T. P. RUBAN, I. M. VAGINA, L.L.LUKASH, 2007 as a response of to the presence of compound like nocodazole [8], the search for mutations resulting in chromosomal instability is narrowed to the search for the mutations of genes of mitotic checkpoint. Similar mutations were detected in some human cell lines, which are characterized by chromosomal instability [9]. However, it has been shown that the damage of mitotic checkpoint primarily results in the death of cells $[1,10]$, and in order to obtain the phenotype of the chromosomal instability, there should be at least additional loss of p53 function [1]. The correlation between chromosomal instability (ploidy change) and the loss or mutational inactivation of $\mathrm{p} 53$ is observed in numerous experimental and clinical investigations [11-17].

Tumour suppressor gene p53 (TP53 in human and Trp53 in mice) is mutated the most in human tumours, its mutations have been revealed in more than $50 \%$ of human tumours [18-20]. Mutational inactivation and/or deletion of p53 is common for different types of tumours in the cases of sporadic and familial cancer dis- 
eases $[18,19]$. Protein $\mathrm{p} 53$ is specific for the numerous functions $[21,22]$, particularly participation in the inhibition of abnormal growth of cells [23] and initiation of apoptosis [24]. $p 53$ has been called the guardian of the genome due to the function of securing the genome integrity and elimination of damaged cells [25]. Besides, some more important functions of $p 53$ are the DNA repair [26] and inhibition of angiogenesis [27]; p53 is know to be the transcription factor of many genes [28]. The activation of target genes by p53 may result in the growth stop either before replication of DNA in G1 phase of cell cycle or prior to mitosis in $\mathrm{G} 2$ phase. The stop in growth enables the cells to repair the damaged DNA while due to apoptosis the damaged cells are eliminated, which prevents the securing the damages in DNA as mutations.

In normal cells p53 protein is non-functional, it is activated as a response to different signals only, e.g. damage of DNA, abnormal proliferative signals, hypoxia, the loss of cell adhesion, etc [27]. In the majority of human tumours p53 is non-functional or incorrect functioning also [27]. Inactivation of $\mathrm{p} 53$ function may be achieved in different ways, in some cases not only through the mutation of $p 53$ gene but also in functional changes of $\mathrm{p} 53$ protein during its binding to virus proteins, localisation of protein in cytoplasm, as a result of changes in protein encoding genes (e.g. Mdm2), associated with $\mathrm{p} 53$ etc [27].

Both the studies on morphological and growth characteristics of new embryonic germ cell line G1 $[29,30]$ and the results detailed cytogenetic analysis [31] testify in favour of spontaneous transformation of the investigated cells in vitro, accompanied by the intensive evolution of karyotype. Different aberrant mitoses revealed [30] as well as high frequencies of aneuploid cells in G1 cell line populations [31] indicate the deregulation of division of cells and weakening of mitotic checkpoint [6]. The presence of chromosomal aberrations in the cells under investigation reveals the disfunctioning of reparation [31, 32]. Therefore, in order to identify possible factors of chromosomal instability in mouse cells in vitro we have analysed the expression of Trp53 on the level of protein and investigated the life capacity of cells of the G1 line after treatment with colchicine at different passages of in vitro cultivation.
Materials and Methods. Cell cultures. Mouse G1 cell line, obtained from embryonic material of BALB/c mouse strain at the Department of Human Genetics of Institute of Molecular Biology and Genetics of NAS of Ukraine, its sublines G1-OA and G1-T, selected by the features of transformed phenotype in vitro $[29,30]$, and 12.5-d.p.c. mouse embryos of BALB/c strain, which were used to obtain mouse cell line G1 [29], were used in the current work.

The cells were cultivated in DMEM medium (Sigma, USA) with $1-10 \%$ of fetal bovine serum (Sigma), $100 \mathrm{units} / \mathrm{ml}$ of penicillin, and $100 \mu \mathrm{g} / \mathrm{ml}$ of streptomycin.

Activity analysis of mitotic checkpoint. To analyse the ability of cells to survive and to divide after the treatment with colchicine, the cells were sown in 96-well plates, 15 thousand each, and incubated at $37^{\circ} \mathrm{C}$ and $5 \% \mathrm{CO}_{2}$ in the growth medium with the corresponding concentration of fetal bovine serum for 24 hours. The next 24 hours the cells were incubated in the growth medium with $0.05,0.5$, and $5 \mu \mathrm{g} / \mathrm{ml}$ of colchicine and with no colchicine addition. The cells without any colchicine were used as control (control 1, $\mathrm{C}-1$ ) and with the addition of colchicine solvent, water, (control 2, C-2) were used as negative control. After the colchicine was washed away, the cells were cultivated for 0 and 48 hours in the growth medium. The solvent was added to the nutrition medium in the volumes, corresponding the colchicine concentrations of 0.5 and $5 \mu \mathrm{g} / \mathrm{ml}$. To calculate the numbers of survived cells in the mentioned above time, the growth medium was added with triazolyl blue tetrazolium bromide (Sigma) in the concentration of $75 \mu \mathrm{g}$ per $1 \mathrm{ml}$ of medium and incubated for 4 hours at $37^{\circ} \mathrm{C}$ and $5 \% \mathrm{CO}_{2}$. The medium was removed, added with dimethyl sulfoxide, $200 \mu \mathrm{l}$ per well, pipetted gently and determined for the spectrophotometric density at $\lambda=540 \mathrm{~nm}$.

Preparation of lysates of mammalian cells. The cells were cultivated to $70-80 \%$ confluence and then were washed twice with phosphate-buffered saline (PBS, pH 7.4) and collected from the glass using 0.02\% EDTA. Cell suspense was washed twice with PBS (pH 7.4) and centrifuged at $15000 \mathrm{rpm}$ for $10 \mathrm{~min}$. The cell pellet was added with the corresponding volume of lysis buffer. The pieces of embryonic tissues of $\mathrm{BALB} / \mathrm{c}$ mouse strain, obtained in aseptic conditions, 
were washed in PBS ( $\mathrm{pH} 7.4$ ), powdered in mortar with liquid nitrogen and incubated with the lysis buffer.

To carry out the immunoprecipitation, lysis of cells was performed for $30 \mathrm{~min}$ on ice in the buffer of the following contents: $0.05 \mathrm{M}$ tris- $\mathrm{HCl}(\mathrm{pH} 8.0), 0.15 \mathrm{M}$ $\mathrm{NaCl}, 0.005 \mathrm{M}$ EDTA, $1 \% \mathrm{NP}-40$, and $0.002 \mathrm{M}$ phenylmethylsulfonyl fluoride.

To carry out the Western Blotting, the cell pellet was added with buffer of: $0.05 \mathrm{M}$ tris $\mathrm{HCl}$ (pH 8.0), 0.15 $\mathrm{M} \mathrm{NaCl}, 0.005 \mathrm{M}$ EDTA, $0.003 \mathrm{M}$ 1,4-dithiotreitol, $0.002 \mathrm{M}$ phenylmethylsulfonyl fluoride and incubated on ice for $30 \mathrm{~min}$. Then the cell lysates were sonicated on ice by ultra-sound three times, $10 \mathrm{sec}$ each, with 30 $\mathrm{sec}$ interval, centrifuged for $30 \mathrm{~min}$ at $4^{\circ} \mathrm{C}$ at $10000 \mathrm{~g}$. The supernatant was transferred to a fresh tube, and the pellet was discarded.

Western Blot analysis of tissue and cell lysates. Bradford's quantitative method was used to determine total protein concentration in cell lysates [31]. Gel-electrophoresis of cell lysates was performed in accordance to the recommendations [34].

Immunoprecipitation and Western Blotting were carried out using the monoclonal anti-p53 antibodies by Chemicon International, USA: 1) PAb240, capable of detecting in denaturated conditions of both forms of p53: wild type and mutants, whereas in the native conditions - only the mutant form and 2) antibodies PAb246, reactive to wild type p53 only. Species-specific antibodies, produced by Jackson ImmunoResearch, USA, conjugated with horse-radish peroxidase were used as secondary antibodies.

Western-Blot analysis was performed according to recommendations, presented in [34]. The proteins were separated by single-level electrophoresis in $10 \%$ SDS-polyacrylamide gels. Separated proteins were transferred from SDS-PAAG to polyvinylidene fluoride membrane (Millipore, USA) using the method of semi-dry transfer in the buffer, which contained $39 \mathrm{mM}$ of glycine, $48 \mathrm{mM}$ basic tris, $0.037 \%$ SDS and $20 \%$ methanol, $\mathrm{pH} 8.3$ and using the method of tank transfer in the buffer of the following contents: $192 \mathrm{mM}$ of glycine, $25 \mathrm{mM}$ tris- $\mathrm{HCl}, 10 \%$ methanol, using the transfer systems of BioRad, USA. After the transfer the membranes were incubated for 1 hour with gentle agitation on a platform shaker to prevent non-specific binding (0.01 M tris-HCl, pH7.5, $0.15 \mathrm{M} \mathrm{NaCl}, 5 \%$ nonfat dried milk). Then, membranes were incubated for 1 hour at room temperature with gentle agitation on a platform shaker in the solution of primary monoclonal antibodies (1 ?g/ml of antibodies in the blocking solution). The membrane was washed three times $10 \mathrm{~min}$ each in buffer, containing $0.01 \mathrm{M}$ tris- $\mathrm{HCl}, \mathrm{pH} 7.5,0.15$ $\mathrm{M} \mathrm{NaCl}$ and $0.1 \%$ of tween-20. Species-specific secondary antibodies, conjugated with horseradish peroxidase, were added as recommended by the manufacturer and incubated with the membrane during 1 hour at room temperature with gentle agitation on a platform shaker.

Chemiluminescent reaction of the membrane was carried out for $1 \mathrm{~min}$ in the solution of: $100 \mathrm{mM}$ tris-HCl, pH 8.5, $1.237 \mathrm{mM}$ 3-aminophthalhydrazide (luminol), $0.673 \mathrm{mM}$ trans-4-hydroxycinnamic acid (p-coumaric acid), and $0.011 \% \mathrm{H}_{2} \mathrm{O}_{2}$. Membrane was exposed to X-ray film, produced by $A g f a$, USA.

Immunoprecipitation. Cell lysates were centrifuged at $10000 \mathrm{~g}$ for $30 \mathrm{~min}$ at $4^{\circ} \mathrm{C}$. $500 \mu \mathrm{g}$ of total protein were incubated with $40 \mu \mathrm{l}$ of $50 \%$ protein A-sepharose during 1 hour, then centrifuged at $30000 \mathrm{~g}$ for $2 \mathrm{~min}$. The lysates was added $15 \mu \mathrm{l}$ of antibodies $(1.5 \mu \mathrm{g})$ and then incubated $\left(4^{\circ} \mathrm{C}, 16\right.$ hours). After incubation with antibodies, $60 \mu \mathrm{l}$ of $50 \%$ protein A-sepharose were added and incubated again $\left(4^{\circ} \mathrm{C}, 1\right.$ hour $)$, then centrifuged at $3000 \mathrm{~g}$ for $2 \mathrm{~min}$. Protein A-sepharose was washed three times in the buffer $(0.05 \mathrm{M}$ tris- $\mathrm{HCl}, \mathrm{pH}$ 8.0, 0.15 M NaCl, $0.005 \mathrm{M}$ EDTA, 1\% NP-40, and $0.002 \mathrm{M}$ phenylmethylsulfonyl fluoride). Protein A-sepharose was added $20 \mu 12 \times$ Laemmli buffer and boiled for $10 \mathrm{~min}$.

Microphotography. Pictures of microobjects were taken using Jenaval microscope (Carl Zeiss, Austria) with lens of $25 \mathrm{x}, 40 \mathrm{x}$, and $100 \mathrm{x}$ using the Canon Powershot digital camera (Canon, UK) and Zoom software.

The statistical analysis of the result obtained was performed according to the method, described in [35].

Results and Discussion. The cell populations of mouse G1 cell line were revealed to have different aberrant mitoses, namely, cells with different numbers of nuclei, micronuclear cells, bridges, C-mitoses, etc, and high frequencies of aneuploid cells at different passages of in vitro cultivation [30,31]. Aberrant mitoses revealed are consequences of both damages of chromo- 

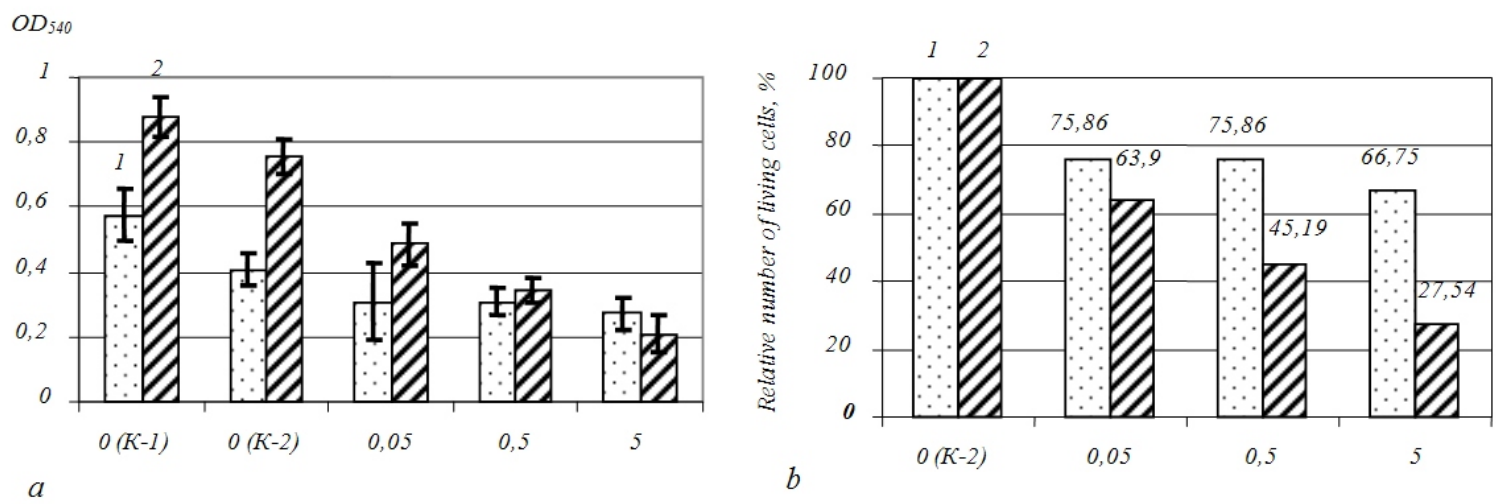

Fig.1 Analysis of activity of mitotic checkpoint in mouse embryonic fibroblasts (MEFs, 2nd passage in vitro): $a-$ the number of living cells, absolute value of optical density ( $1-0$ hours; $2-48$ hours); $b$ - relative number of living cells in comparison to the control ( $1-0$ hours; $2-$ 48 hours); absciss - colchicine concentration, $\mu \mathrm{g} / \mathrm{ml}, C-1$ - control (cells only); $C-2$ - control 2 (cells and colchicine solvent - water)

somes and mitotic apparatus and cytotomy [36]. The loss or gain of chromosomes in cells, cancer cells in particular, are known to be the results of aberrant mitoses [37]. Eukaryotic cells are specific for the existence of a qualitative mechanism, controlling the normal course of mitosis i.e. mitotic checkpoint, which provides correct distribution of chromosomes during cell division $[6,7]$. Supposedly, mitotic checkpoint in the cells of the investigated mouse cell line G1 is either partially active or inactive at all.

The cells of defected mitotic checkpoint are not capable of terminating its division if the chromatides are not attached to the spindle fibers or attached inproperly as well as also in the case of damaged kinetochore or formed several spindle poles (so called multi-polar mitoses) etc $[6,7]$. Thus the cells onset premature anaphase. Normal cells, treated with solution depolymerising spindle microtubule or inhibiting the formation of one, stop in the cell cycle and do not enter the mitosis as their mitotic checkpoint is activated [38, 39]. The cells with damaged mitotic checkpoint are not capable of terminating their division after treatment with mitotic poisons, e.g. nocodazole, colchicine, colcemide, etc [8]. Therefore, we have tested G1 cells at the $26^{\text {th }}$ and $114^{\text {th }}$ passages of in vitro cultivation for their capability to surviving and dividing after treatment with colchicine of different concentrations. The relative number of living cells, obtained testing the normal cells - mouse embryonic fibroblasts (MEFs) isolated from 12.5-d.p.c. BALB/c mouse embryos, were used as the control.
It was revealed that the number of living cells decreased after MEFs incubation with colchicine of different concentrations in no time after the change of the medium (Fig.1). The comparison with the control (cells and solvent) revealed the number of cells to decrease app. 24-33\% (Fig.1, b). In 48 hours after the change of the growth medium, the number cells increased in both controls, at the same time their number decreased in the wells, treated with different concentrations of colchicine (Fig.1). The cells, treated with 0.05 $? \mathrm{~g} / \mathrm{ml}$ colchicine were the least sensitive $-63.9 \%$ of cells survived; average sensitivity of cells to $0.5 ? \mathrm{~g} / \mathrm{ml}$ was $45.19 \%$ and MEFs were the most sensitive to 5 ?g/ml colchicine per $1 \mathrm{ml}$ of medium - 27.54\% (Fig.1, $b)$. This fact reveals the correlation between the MEFs sensitivity and colchicine concentration. Thus, we have defined effective proliferation blocking and significant decrease in the number of living cells in MEFs population after treatment with colchicine, which also testifies to the functional activity of mitotic checkpoint in MEFs.

The number of G1 living cells at the $26^{\text {th }}$ passage after treatment with colchicine in different concentrations decreased insignificantly (Fig.2, $a$ ). The comparison with the control revealed app. 13-14\% decrease in the number of cells (Fig.2, b). In 48 hours after change of the medium, the number of living cells at $0.05 ? \mathrm{~g} / \mathrm{ml}$ colchicine exceeded that of MEFs and amounted $76.86 \%$ (Fig. 1, Fig. 2, $a, b$ ). The number of survived G1 cells was also increased at the $26^{\text {th }}$ passage, compared to MEFs, after treatment with 0.5 and $5 \mu \mathrm{g} / \mathrm{ml}$ of 

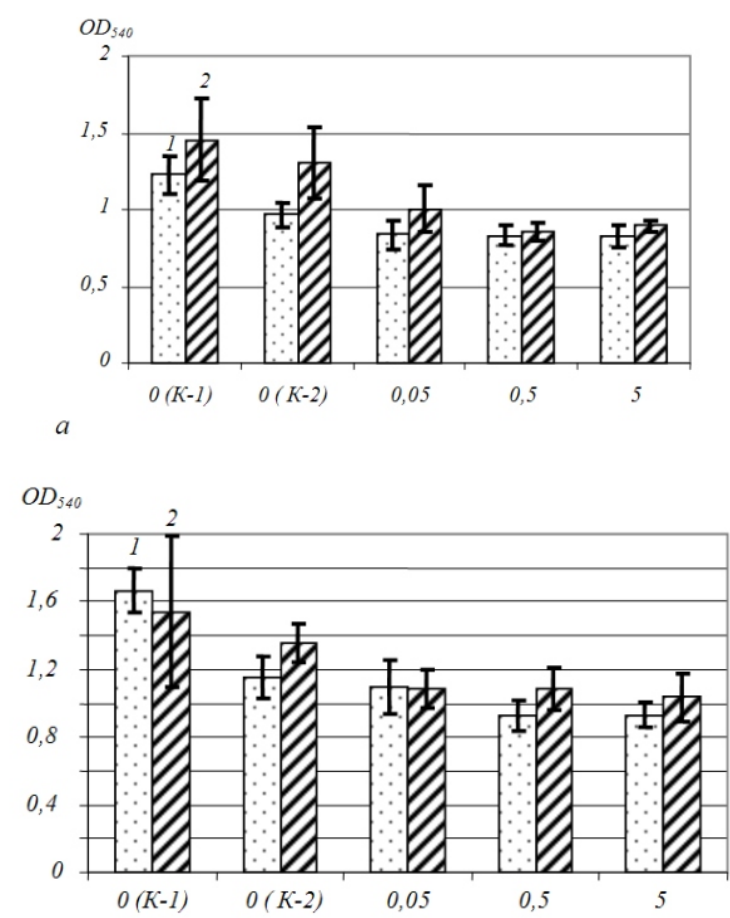

c

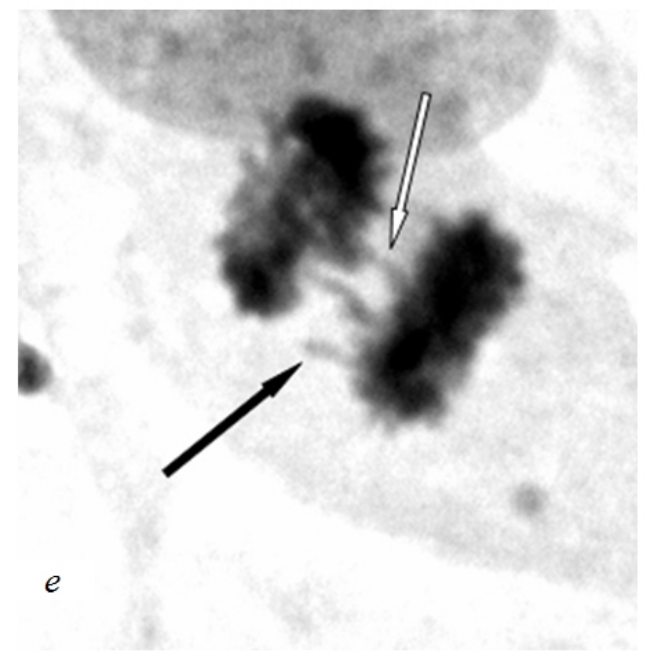

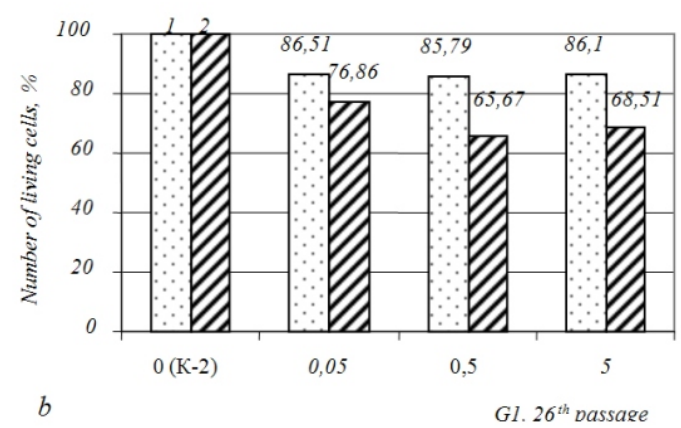

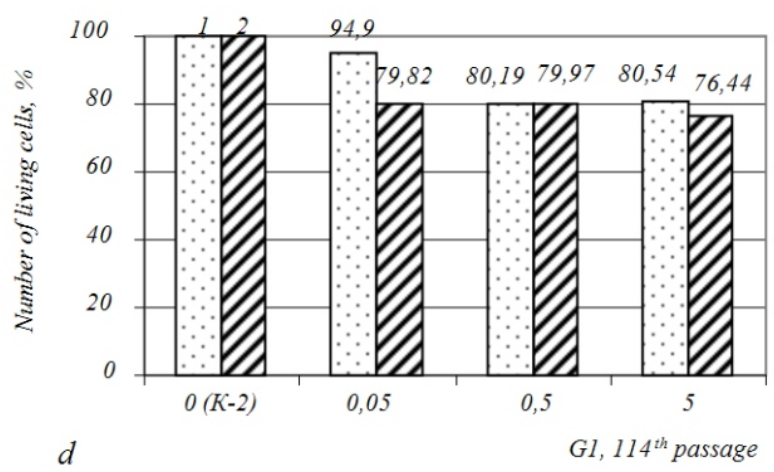

Fig.2 Analysis of activity of mitotic checkpoint in the cells of mouse G1 cell line: $a$-number of living cells at the 26th passage, absolute values of optical density; $b$-relative number of living cells at the 26 th passage, compared to the control; $c$-number of living cells at the 114th passage, absolute value of optical density; $d$-relative number of living cells at the 114 th passage, compared to the control ( $a-d$ : $1-0$ hours, $2-48$ hours); absciss - colchicine concentration, $\mu \mathrm{g} / \mathrm{ml}, C-1-$ control (cells only); $C-2-$ control 2 (cells and colchicine solvent - water); $e$ - anaphase of G1 line cells at the 104th passage of in vitro cultivation with chromosomal delay (black arrow) and bridges between groups of anaphase chromosomes (white arrow); lens 100x, ocular 10x.

colchicine (Fig.2), 65.67 and $68.51 \%$, respectively. No significant difference has been discovered in the sensitivity of the investigated G1 cells to the concentration of colchicine of 0.5 and $5 \mu \mathrm{g} / \mathrm{ml}$. Therefore, the activity of mitotic checkpoint at the $26^{\text {th }}$ passage of cultivation of cells of the mouse G1 cell line is lower, compared with MEFs.

The analysis of the activity of the mitotic checkpoint of G1 cells at the $114^{\text {th }}$ passage of in vitro cultiva- tion revealed the highest number of survived cells after the treatment with colchicine, in comparison with the $26^{\text {th }}$ passage and MEFs. The number of survived cells in comparison with the control decreased $~ 5 \%$ only at the treatment of colchicine of $0.05 ? \mathrm{~g} / \mathrm{ml}$ and $\sim 20 \%$ at 0.5 and $5 \mu \mathrm{g} / \mathrm{ml}$ (Fig.2, $c, d$ ). In 48 hours after the change of the growth medium, the number of survived cells at different colchicine concentrations was at a rather high level $(79.82,79.97$, and $76.44 \%$ of survived cells at the 


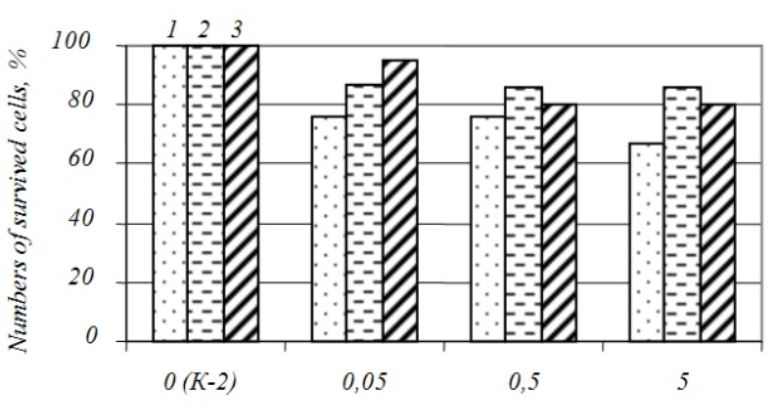

$a$

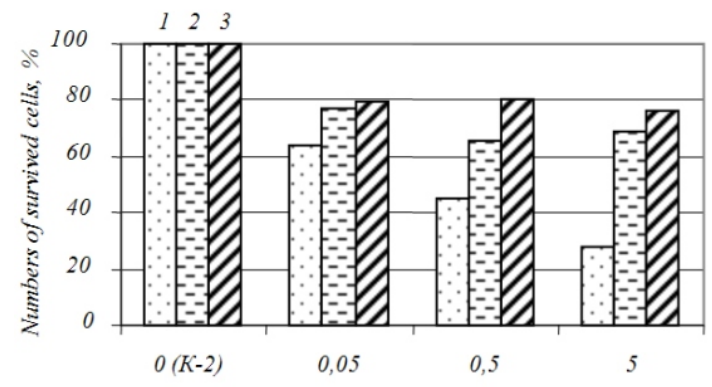

$b$

Fig. 3 Numbers of survived cells compared to the control: $a-0$ hours and $b-48$ hours of cell growth, prior treated with different colchicine concentrations, after the change of growth medium (1 - MEFs, 2nd passage; 2 - G1, 26th passage; 3 - G1, 114th passage); absciss colchicine concentration, $\mu \mathrm{g} / \mathrm{ml}, C-1-$ control (cells only); $C-2-$ control 2 (cells and colchicine solvent - water)

aforementioned colchicine concentrations) (Fig.2). Therefore, the cells of mouse G1 cell line were revealed to be insensitive to different concentrations of colchicine at the $114^{\text {th }}$ passage of in vitro cultivation, which testifies about weakened mitotic control.

The analysis of mitotic checkpoint in MEFs and in G1 cell line at the $26^{\text {th }}$ and $114^{\text {th }}$ passages on in vitro cultivation also revealed MEFs to be the most sensitive to the effect of different concentrations of colchicine. G1 cells were shown to be less sensitive at both early and late passages (Fig.3, $a$ ).

In 48 hours of growing of cells after the change of the medium, the significant difference in the number of survived cells in MEFs population at different colchicine concentrations was observed as well as in the numbers of survived cells in MEFs and G1 populations (Fig. 3, b). G1 cells were revealed to be insensitive to the effect of different concentrations of colchicine, whereas every 10-time increase in colchicine concentrations, MEFs were shown both not to divide and die. Therefore, the lower sensitivity of G1 cells to the effect of colchicine at the $26^{\text {th }}$ and $114^{\text {th }}$ passage of cultivation, compared to MEFs, was revealed, while the cells at the $114^{\text {th }}$ passage were specific for the lowest sensitivity (Fig.3).

The inactivation of mitotic checkpoint in cells of the mouse G1 cell line is evidenced by the premature separation of centromeres, compared with sister chromatides, revealed at the $15^{\text {th }}$ passage of in vitro cultivation [40]. The factors, causing the loss of chromosome, the formation of micronuclei, and aneuploidy of the investigated cell line, may include not only the spin- dle defects (as multi-nuclear cells in the G1 cell population and multipolar mitoses in their sublines were observed) but also the defects of kinetochores, particularly delay in anaphase of chromosomes (Fig.2,e).

Therefore, the obtained results reveal that the disfunction of mitotic checkpoint is responsible for the chromosomal instability of the cells of mouse G1 cell line.

Some other factors are involved in the occurrence of phenotype of chromosomal instability in mammalian cells, e.g. the loss of function of tumorsupressor $\mathrm{p} 53$ [1]. Fibroblasts of p53-/- of mice were shown to reveal high aneuploidy $[11,12-16]$. The correlation between mutation or deletion of p53 and the occurrence of aneuploidy have been established in various human tumours [17].

The mechanisms of $\mathrm{p} 53$ inactivation prior to the occurrence of chromosomal instability have not been clarified yet. One of the known mechanisms is presented by the regulation of cycle of centrosome duplication during p53 inactivation $[11,41,42]$. Thus, loss of p53 was shown to result in hyper-amplification of centrosomes in mouse cells in vitro, as a result high frequency of aberrant mitoses (multipolar mitoses and damaged cytokinesis) was observed, which in its turn results in the increase in number of errors in the transfer of chromosomes to the sister cells $[11,41]$. Other possible mechanisms are related to $\mathrm{p} 53$ regulation of the cell cycle and apoptosis.

Therefore, we have analysed the expression of Trp53 gene in the cells of mouse G1 cell line and its sublines G1-OA and G1-T at different passages of in vi- 

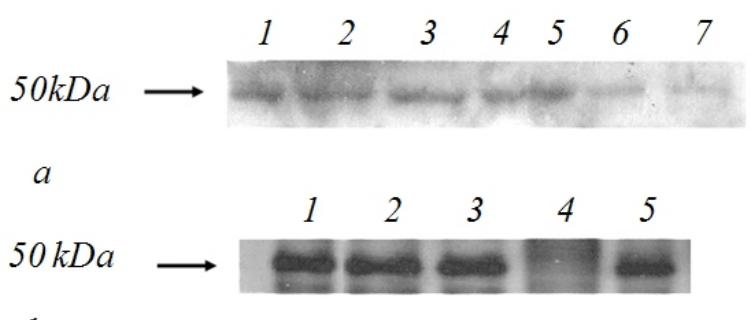

$b$

Fig.4 P53 protein detection: a - Western-Blot analysis of p53 with monoclonal antibodies PAb240 in cells: 1 - MEFs; $2-\mathrm{G} 1$, 30th passage; 3 - G1, 106th passage; 4 - G1-OA, 35th/24th passages; 5 G1-OA, 35th/65th passage; $6-\mathrm{G} 1-\mathrm{T}, 66 \mathrm{th} / 17 \mathrm{th}$ passage; $7-\mathrm{G} 1-\mathrm{T}$, 66th/35th passage; $b$ - immunoprecipitation of p53 with PAb240 antibodies $(1,2,4)$ and PAb246 $(3,5)$ from protein extracts of cells: 1 - G1, 30th passage; 2, 3-G1, 106th passage; 4, 5 - MEFs

tro cultivation using the methods of Western Blotting and immunoprecipitation. Western Blotting was carried out on monoclonal antibodies PAb240, which in the denaturated conditions recognised both forms (native and mutant) of p53 protein [43, 44]. Immuneprecipitation was performed with antibodies PAb246, specific to wild type p53, and PAb240, which at the native conditions are bound with mutant p53 only $[43,44]$.

Low level of p53 was revealed in all investigated cell cultures using Western Blotting (Fig.4, a). MEFs lysates were used as the positive control of p53 expression.

As PAb240 at denaturated conditions allows detecting $\mathrm{p} 53$ of both mutant and wild types, therefore, to determine which of the forms of p53 is present in G1 cells we have performed immunoprecipitation of p53 at the native conditions with PAb240 and pAB246 antibodies. At these conditions PAb240 are bound to mutant p53 only and PAb246 with wild type p53. Only wild type p53 was immunoprecipitated from the MEFs lysates. At the same time lysates of the G1 cells at the $106^{\text {th }}$ passage of cultivation in vitro revealed the immunoprecipitation of both wild and mutant p53 forms (Fig.4, $b$ ). Mutant $\mathrm{p} 53$ were detected at the $30^{\text {th }}$ and $106^{\text {th }}$ passages of in vitro cultivation of G1 cells (Fig.4, $b$ ). The presence of mutant and wild p53 forms may result in functional inactivation of p53 due to the formation of p53-tetramere between wild type p53 and mutant p53, as it has been described in $[45,46]$.
Therefore, the analysis of p53 expression revealed the mutant form of p53 in G1 line cells at the $30^{\text {th }}$ and $106^{\text {th }}$ passages of in vitro cultivation. These data correlate with the results of analysis of activity of mitotic checkpoint in the investigated cells. Chromosomal instability and destabilisation of cell line karyotype are expected to increase at the conditions of weakened mitotic control and the absence of functional p53. It is possible that simultaneous inactivation of mitotic checkpoint and expression of p53 of both types may provide the explanation to extended stage of establishment in vitro of mouse G1 cell line with intensive evolution of karyotype [31].

Thus, having performed the analysis of survivability of the cells of mouse G1 cell line and divisibility after treatment with colchicine, it is possible to conclude the weakening of function of mitotic checkpoint at different passages of in vitro cultivation. Western-Blot analysis allowed low-level detection of p53 protein in the cells of G1 line as well as in its sublines G1-OA and G1-T, whereas the immunoprecipitation of $\mathrm{p} 53$ protein at the native conditions revealed the mutant $\mathrm{p} 53$ form in the $\mathrm{G} 1$ cells at the $30^{\text {th }}$ and $106^{\text {th }}$ passages of in vitro cultivation. Both wild type and mutant p53 were detected at the $106^{\text {th }}$ passage of $\mathrm{G} 1$ cells. Summarising the stated above it has to be said that increased chromosomal instability and intensive process of karyotypic evolution of spontaneously immortalised mouse G1 cell line [29, $31,32]$, as well as aberrant mitoses in the cells of this line are due to the damages in regulation of mitosis and possibly inactivation of $\mathrm{p} 53$.

The work was partially supported by Ukrainian Fundamental Research State Fund of Ministry of Science and Education of Ukraine, project No.Ф18/11-2006.

\section{А. П. Яцьишина, С. М. Кваша, О. В. Пидпала, Т. П. Рубан, И. Н. Вагина, Л. Л. Лукаш}

Генетическая нестабильность эмбриональных герминативных клеток линии G1 мыши и нарушение функций контрольной точки митоза и р53

Резюме

Изучена выживаемость мышиных клеток линии G1 при обработке колхицином в разных кониентрачиях. Установлена меньшая чувствительность к действию колхицина клеток линии G1 на 26-м и 114-м пассажах по сравнению с эмбриональ- 
нымми фибробластами мыми линии $B A L B / c$, что свидетельствует об ослаблении контрольной точки митоза в клетках линии G1. При помощи Вестерн-блот анализа выявлен белок р53 на низком уровне как в клетках линии G1, так и ее сублиний G1-OA и G1-T. Методом иммунопреципитации в клетках линии G1 определено присутствие белка р53 обоих типов: как дикого, так и мутантного, что может вызвать нарушение его функции. Генетическая нестабильность клеток линии G1 мыши связана с нарушением функиии контрольной точки митоза и, вероятно, с функциональной инактивацией p53.

Ключевые слова: клетка мыши in vitro, контрольная точка митоза, хромосомная нестабильность, p53.

\section{REFERENCES}

1. Burds A. A., Lutum A. S., Sorger P. K. Generating chromosome instability through the simultaneous deletion of Mad2 and p53 // Proc. Nat. Acad. Sci. USA.-2005.-102.P. $11296-11301$.

2. Cheng K. C., Loeb L. A. Genomic instability and tumor progression: mechanistic considerations // Adv. Cancer Res.-1993.-60.-P. 121-156.

3. Holliday R. Chromosome error propagation and cancer // Trends Genet.-1989.-5.-P. 42-45.

4. Nowak M. A., Komarova N. L., Sengupta A., Jallepalli P. V., Shih I. M., Vogelstein B., Lengauer $C$. The role of chromosomal instability in tumor initiation // Proc. Nat. Acad. Sci. USA.-2002.-99.-P. 16226-16231.

5. Draviam V. M., Xie S., Sorger P. K. Chromosome segregation and genomic stability // Curr. Opin. Genet. Develop.-2004.-14.-P. 120-125.

6. Rudner A. D., Murray A. W. The spindle assembly checkpoint // Curr. Opin. Cell Biol.-1996.-8.-P. 773-780.

7. Biggins $S$., Murray A. W. Sister chromatid cohesion in mitosis // Curr. Opin. Cell Biol.-1998.-10.-P. 769-775.

8. Jallepalli $P$. V., Lengauer C. Chromosome segregation and cancer: cutting through the mystery // Nat. Rev. Cancer.-2001.-1.-P. 109-117.

9. Cahill D. P., Lengauer C., Yu J., Riggins G. J., Willson J. K., Markowitz S. D., Kinzler K. W., Vogelstein B. Mutations of mitotic checkpoint genes in human cancers // Nature.-1998.-392.-P. 300-303.

10. Kops G. J. P. L., Foltz D. R., Cleveland D. W. Lethality to human cancer cells through massive chromosome loss by inhibition of the mitotic checkpoint // Proc. Nat. Acad. Sci. USA.-2004.-101.-P. 8699-8704.

11. Fukasawa K., Wiener F., Vande Woude G. F., Mai S. Genomic instability and apoptosis are frequent in p53 deficient young mice // Oncogene.-1997.-15.P. 1295-1302.

12. Harvey M., McArthur M. J., Montgomery C. A., Butel J. S., Bradley A., Donehower L. A. Spontaneous and carcinogen-induced tumorigenesis in p53-deficient mice // Nat. Genet.-1993.-5.-P. 225-229.

13. Harvey M., Sands A. T., Weiss R. S., Hegi M. E., Wiseman R. W., Pantazis P., Giovanella B. C., Tainsky M. A., Bradley A., Donehower $L$. $A$. In vitro growth characteristics of embryo fibroblasts isolated from p53-deficient mice // Oncogene.-1993.-8.-P. 2457-2467.

14. Purdie C. A., Harrison D. J., Peter A., Dobbie L., White S., Howie S. E., Salter D. M., Bird C. C., Wyllie A. H., Hooper M. $L$. Tumour incidence, spectrum and ploidy in mice with a large deletion in the p53 gene // Oncogene.-1994.-9.P. 603-609.

15. Bouffler S. D., Kemp C. J., Balmain A., Cox R. Spontaneous and ionizing radiation-induced chromosomal abnormalities in p53-deficient mice // Cancer Res.-1995.-55.P. 3883-3889.

16. Donehower L. A., Godley L. A., Aldaz C. M., Pyle R., Shi Y. P., Pinkel D., Gray J., Bradley A., Medina D., Varmus H. E. Deficiency of p53 accelerates mammary tumorigenesis in Wnt-1 transgenic mice and promotes chromosomal instability // Genes Develop.-1995.-9.-P. 882-895.

17. Hainaut P., Hollstein M. p53 and human cancer: the first ten thousand mutations // Adv. Cancer Res.-2000.-77.P. 81-137.

18. Hollstein M., Sidransky D., Vogelstein B., Harris C. C. p53 mutations in human cancers // Science.-1991.-253.P. 49-53.

19. Levine A. J., Momand J., Finlay C. A. The p53 tumour suppressor gene // Nature.-1991.-351.-P. 453-456.

20. Lane D. P., Benchimol S. p53: oncogene or anti-oncogene? // Genes Develop.-1990.-4.-P. 1-8.

21. Ko L. J., Prives C. p53: puzzle and paradigm // Genes Develop.-1996.-10.-P. 1054-1072.

22. Mowat M. R. p53 in tumor progression: life, death, and everything // Adv. Cancer Res.-1998.-74.-P. 25-48.

23. Sionov R. V., Haupt $Y$. The cellular response to p53: the decision between life and death // Oncogene.-1999.-18.P. 6145-6157.

24. Heinrichs S., Deppert $W$. Apoptosis or growth arrest: modulation of the cellular response to $\mathrm{p} 53$ by proliferative signals // Oncogene.-2003.-22.-P. 555-571.

25. Lane D. P. P53, guardian of the genome // Nature.-1992.358. -P. 15-16.

26. Albrechtsen N., Dornreiter I., Grosse F., Kim E., Wiesmuller L., Deppert $W$. Maintenance of genomic integrity by $\mathrm{p} 53$ : complementary roles for activated and non-activated p53 // Oncogene.-1999.-18.-P.7706-7717.

27. Vogelstein B., Lane D., Levine A. J. Surfing the p53 network // Nature.-2000.- 408.-P. 307-310.

28. el-Deiry W. S. Regulation of p53 downstream genes // Semin Cancer Biol.-1998.-8.-P. 345-357.

29. Лукаш Л. Л., Яичшина А. П., Підпала О. В., Вагіна І. М., Кочубей Т. П. Одержання нових ліній стовбурових клітин миші i вивчення впливу мікрооточення на їхню каріотипічну мінливість in vitro // Физиология и биохимия культурных растений.-2006.-38, № 2.-С. 144-152.

30. Яиишина А. П., Підпала О. В., Рубан Т. П., Тімошук О. В., Лукаш Л. Л. Цитоморфологічна характеристика нової клітинної лінії миші G1 // Цитология и генетика.-2006.-40, № 3.-С. 49-58.

31. Яичиина А. П., Підпала О. В., Кочубей Т. П., Лукаш Л. Л. Цитогенетичний аналіз спонтанно імморталізованої клітинної лінії G1 миші // Біополімери i клітина.-2006.-22, № 4.-С. 299-306.

32. Яичишина А. П., Підпала О. В., Кочубей Т. П., Лукаш Л. Л. Спонтанна каріотипічна еволюція клітин миші in vitro // Фактори експериментальної еволюції організмів.-К.: Аграрна наука, 2004.-T. 2.-С. 88-92. 
33. Bradford M. M. A rapid and sensitive method for the quantitation of microgram quantities of protein-dye binding // Anal. Biochem.-1976.-72.-P. 248-254.

34. Sambrook J., Fritsh E. F., Maniatis T. Molecular cloning: a laboratory manual.-New York: Cold Spring Harbor Lab. press, 1989.

35. Плохинский Н. А. Алгоритмы биометрии / Под ред. акад. АН СССР Б. В. Гнеденко.-М.: Изд-во МГУ, 1980.-150 с.

36.Алов И. А. Цитофизиология и патология митоза.-М.: Медицина, 1972.-264 с

37. Carroll P. E., Okuda M., Horn H. F., Biddinger P., Stambrook P. J., Gleich L. L., Li Y.-Q., Tarapore P., Fukasawa $K$. Centrosome hyperamplification in human cancer: chromosome instability induced by p53 mutation and/or Mdm2 overexpression// Oncogene.-1999.-18.P. 1935-1944.

38. Sentein $P$. Inhibition of spindle assembly by colchicine and of cell cycle by cycloheximide. Comparison and combination of their cytological action on cleavage mitosises // Exp. Cell Biol.-1979.-47.--P. 368-391.

39. Wang Y., Burke D. J. Checkpoint genes required to delay cell division in response to nocodazole respond to impaired kinetochore function in the yeast Saccharomyces cerevisiae // Mol.Cell. Biol.-1995.-15.-P. 6838-6844.

40. Глазко Т. Т., Яцышина А. П., Пидпала О. В., Вавилина И. В., Лукаш Л. Л. Источники гетерогенности культивируемых in vitro популяций эмбриональных клеток мыши ли- нии BALB/c // Біополімери і клітина.-2006.-22, № 5.C. $350-354$.

41. Fukasawa K., Choi T., Kuriyama R., Rulong S., Vande Woude G. F. Abnormal centrosome amplification in the absence of p53 // Science.-1996.-271.-P. 1744-1747.

42. Tarapore P., Fukasawa K. Loss of p53 and centrosome hyperamplification // Oncogene.-2002.-21.-P. 6234-6240.

43. Yewdell J. W., Gannon J. V., Lane D. P. Monoclonal antibody analysis of p53 expression in normal and transfrormed cells // J. Virol.-1986.-59.-P. 444-452.

44. Gannon J. V., Greaves R., Iggo R., Lane D. P. Activating mutations in $\mathrm{p} 53$ produce a common conformational effect. A monoclonal antibody specific for the mutant form // EMBO J.-1990.-9.-P. 1595-1602.

45. Branchmann R. K., Vidal M., Boeke J. D. Dominant-negative p53 mutations selected in yearst hit cancer hot spots // Proc. Nat. Acad. Sci. USA.-1996.-93.-P. 4091-4095.

46. Моргункова А. А., Алмазов В. П., Струнина С. М., Копнин Б. П., Чумаков П. М. Доминантно-негативная инактивация р53: влияние количественных соотношений трансдоминантного ингибитора и его мишеней // Молекуляр. биология.-2003.-37, № 1.-С. 112-120.

УдК $576.5+576.35: 576.356+577.21$

Надійшла до редакції 09.04.07 